\title{
Adversity Vanquished: Memoirs of a McGill Medical Student, Harold W. Trott, 1918-1924
}

\section{by Robert H. Michel}

\begin{abstract}
This article examines the first half of the autobiography of Harold Trott (1899-1961), Campus Shadows, which describes his life as a medical student at McGill University between 1918 and 1924. It is one of the most detailed memoirs by a McGill student for any period. Trott wrote about bis lectures, dissecting labs, clinics, bull sessions, money problems, professors, classmates, rowdy student initiations, and life at McGill's Strathcona Hall residence and in Montreal rooming houses. His account is augmented and verified by background from student publications and the McGill University Archives. In his first year at McGill, Trott faced poverty, despair, and a paralyzing disease, the Landry-Guillain-Barré-Strobl Syndrome, which be described strikingly from the patient's viewpoint and which he survived with the belp of Dr. Colin Russel and the staff of the Royal Victoria Hospital. Trott described his long, painful recovery, including two interim years at University of Western Ontario, his final two years at McGill, and how he used the lessons from his medical training in his later medical practice, advocating natural remedies such as drinking water rather than drugs and pills. Practicing in New York State, he sympatbized mildly with the idea of state-funded medical care, which was being advocated in his native Canada.
\end{abstract}

\section{RESUMÉ}

Cet article examine la première moitié de l'autobiographie de Harold Trott (1899-1961), Campus Shadows, qui décrit sa vie à titre d'étudiant en médecine à l'Université McGill entre 1918 et 1924. Les mémoires de Trott sont parmi les auvres les plus détaillées de ce genre qu'un étudiant de McGill de n'importe quelle époque a rédigé. Il décrit ses cours, ses laboratoires de dissection, ses cliniques, ses discussions entre bommes, ses problèmes d'argent, ses professeurs, des séances bruyantes d'initiation d'étudiants, et sa vie à la résidence Strathcona Hall de McGill et dans des chambres à louer de Montréal. Son compte-rendu est élargi et vérifié à l'aide d'information provenant de publications étudiantes et des Archives de l'Université McGill. Au cours de sa première année à McGill, Trott fut confronté à la pauvreté, au désespoir, et à une maladie paralysante, le syndrome Landry-Guillain-Barré-Strobl, qu'il a décrit vivement du point de vue du patient et qu'il a survécu avec l'aide du docteur Colin Russel et du personnel de l'Hôpital Royal Victoria. Trott décrit sa longue et douloureuse guérison, incluant deux années intérimaires à l'University of Western Ontario, ses deux dernières années à McGill, et raconte comment il a par la suite utilisé les leçons de sa formation médicale dans sa pratique médicale, préférant les remèdes naturels comme la consommation d'eau plutôt que les drogues et les pilules. Pratiquant dans l'état de New York, il avait une certaine sympatbie envers l'idée des soins médicaux financés par l'état, dont on faisait la promotion à cette époque dans son Canada natal. 


\section{INTRODUCTION}

I

n 1944, as World War II was ending, Harold Williams Trott (M.D.C.M., McGill 1924), a doctor in upstate New York, published his autobiography, Campus Shadows (reissued in 1946). ${ }^{1}$ Filled with anecdotes, it was half a memoir of McGill (and to lesser extent the University of Western Ontario) and half an attack on medical practices in the United States. Trott's narrative offered a detailed look at the training, social life and concerns of a McGill medical student of modest means between 1918 and 1924. It is a nonfictional counterpart to Dink Carroll's unpublished novel about McGill in the 1920s, described in Fontanus XI. ${ }^{2}$ Trott and Carroll both set down striking records of their student experiences. While Carroll wrote an autobiographical novel, Trott wrote an autobiography in the style of a novel, full of dialogue - book sellers' descriptions occasionally mistake his book for fiction. Carroll's novel was about a student from Toronto resembling himself who went to McGill to play football, enjoy fraternity life and expand his mind on the way. Trott's autobiography was a true Horatio Alger story about a South Western Ontario farmer's son going to McGill to fulfil his childhood dream of becoming a physician, while scrabbling constantly for money to pay room, board and tuition. Carroll's alter ego was out for adventure and lucky; Trott was more resourceful than adventurous, and unlucky. In both narratives, the protagonists overcame adversity - Carroll on the football field and at his books, Trott in a hospital bed. A comparison of their narratives raises the usual questions about the differences between truth and fiction, novels and memoirs, memory and invention, which philosophers, critics, historians, psychologists and neurologists have asked since Herodotus and Homer: Which parts are fact? Which are fiction? Is fiction just another form of reality? Or a cover for failing memory? Carroll and Trott did not worry about such questions. Their imagined and remembered student lives still lurk fourth-dimensionally inside the old Arts Building and the Strathcona Medical Building. While only a few of Carroll's novel's characters can be traced to real life originals, nearly all the people Trott mentioned can be verified as students or staff.

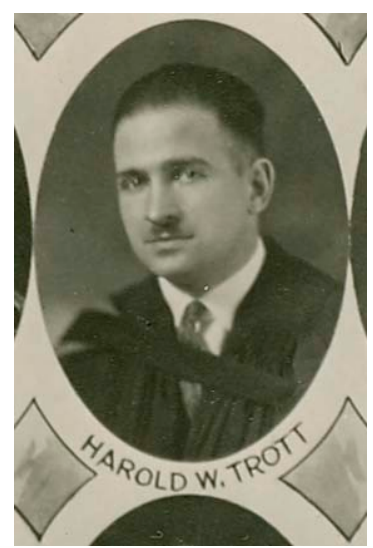

Figure 1. Harold Trott, detail portrait, ca. 1924, from composite group portrait of the Faculty of Medicine, class of 1924. Rice Studio Montreal. McGill University Archives, PL006121.

The medical program took five years. Trott took his first year of medicine, 1918-1919, at McGill; lost the year 1919-1920 to deadly illness; took his second and third years, 1920-1921 and 19211922, at the University of Western Ontario; and returned to McGill for his fourth and fifth years, 1922-1923 and 1923-1924, graduating in 1924 (Fig. 1). Since he seldom put dates to events, they are supplied here, with the help of other sources. Trott's title, Campus Shadows, reflects the importance he placed on his training at both McGill and Western. However, the drawing on the dust jacket of both the 1944 and 1946 editions confirms his emphasis on McGill, translating the vague title into the unmistakable image of McGill's campus. The jacket drawing is an unsigned sketch of the Roddick Gates, with the old grey stone buildings and elms casting the "campus shadows" that Trott remembered watching from his residence on Sherbrooke Street opposite the lower campus, as the sun set one evening in April 1919, just before paralysis 
buried him alive like a victim in an Edgar Allen Poe story. His recollections expose a harsher student life than we experience now in the days of student loans, bursaries and scholarships, rich parents, and the end of hazing and of restrictions on sexual freedom. To pay his way, Trott took hard jobs - furnace stoking, snow shoveling, and waiting tables in restaurants.

Frequent quotations will let Trott speak for himself. The numbers of the pages quoted from Campus Shadows (typeset and paginated identically in both editions, 1944, 1946) follow in parentheses. Trott's narrative is supplemented with excerpts from the McGill Daily and other information and images from his student years, mainly drawn from the McGill University Archives' holdings.

\section{TROTT'S PRACTICE AND MEDICAL PHILOSOPHY}

Campus Shadows had two main subjects - Trott's university training and how he put his lessons into practice as a down-to-earth doctor. While we examine the McGill part here, most people would have read it for its exposé of American medical practice from inside the doctors' club. The reviewers' notes on the front flap of the dust jacket of the 1946 edition declare, "At last, the book all honest doctors and people have been waiting for. The book which exposes the pill retailing profession... It champions the cause of socialized medicine," wrote Charlotte Breitmayer. "A tremendously interesting adventure in living," added Marie B. Coffey. "Campus Shadows has a vital message for everyone in the post-war world, for it breathes the triumphant spirit of all that made America great," declared Mary MorseBailey. Trott's book attacked pill popping - the over-dependence of doctors and neurotic patients on unnecessary pills and prescription drugs as well as the army of pharmaceutical salesmen who sold doctors the pills and potions. Patients demanded pills as magical cures; doctors were forced to prescribe them as placebos to calm the patients; and travelling pharmaceutical salesmen and compliant doctors made money out of them.

In contrast, following his teachers at McGill and Western, Trott tried, not always successfully, to avoid prescribing unproven drugs. Instead, he advocated natural or near-homeopathic approaches, especially the old cure of rest and drinking water to clean out poisons. He complained that too much of his time was wasted by hypochondriacs demanding the latest pills. Criticizing the commercialized side of medical practice, Trott mildly flirted with the idea of "state medicine," which would not be introduced in North America until 1962, in Saskatchewan, by Premier Tommy Douglas. Trott, however, was no social reformer and like most doctors often complained about patients who did not pay their bills. But while he did not advocate full-scale socialized medicine, he suggested that government should distribute remedies for diphtheria and other diseases.

\section{MCGILL, 1918-1919}

Trott was born in August, 1899 and died in May, 1961. He was a farmer's son from Mount Brydges, southwest of London, Ontario. He chose his future profession when he was eight, after he had visited an uncle with fatal anemia in hospital. A doctor gave him a fascinating tour; and on the horse buggy going home Trott announced he would be a doctor. The boy began to experiment on rats he trapped, vivisected woodchucks, and read what medical texts he could find. After he graduated from high school, he worked all summer to pay for his first year at McGill, saving a nest egg of $\$ 850$, which he deposited, fatefully, at his local bank, which soon would fail.

It is not surprising Trott that chose McGill. Medicine was McGill's pre-eminent Faculty; in 1829 its ancestor, the Montreal Medical Institution, had been engrafted on to the struggling new college as its first faculty. In a speech to the Medical Faculty on 19 March 1921, the recently-appointed Principal, Sir 
Arthur Currie, declared: "More than any other department our Medical School has the right to participate in the glories of our college, has a right to claim it has been responsible in a major degree for whatever contribution McGill has made to the welfare, prosperity and happiness of mankind."3

\section{ARRIVAL IN MONTREAL}

In Fall 1918 Trott takes the train for Montreal, traveling second class, with $\$ 37$ and his lunch in his pocket, and imagines the day when as a successful doctor he will be able to afford lunch in the dining car. How many ambitions have been provoked by the railways' and the airlines' division of passengers into cattle and the elect! He hears the "strange sounding French" of fellow travelers, not like the French he learned in high school. Unlike Dink Carroll's protagonist, arriving on the same line from Toronto, Trott makes no resolve to improve his French. He describes his first taste of Montreal - Canada's metropolis of English money and French romance. At Windsor Station, Trott collects his bags, gets on a street car and asks to get off on the "Main street," since he had heard McGill was near the main business street [St. Catherine Street]. He ends up on St. Lawrence Boulevard, known locally as "the Main." This was the street of restaurants, meat markets, fruit stands, and clothing stores dividing Montreal between the English to the west and the French to the east. As a small town, native English-Canadian, Trott is put off by the shops and the scrambling East European immigrants who ran many of them.

I stepped from the car and found myself in the filthiest, foulest-smelling location I had ever imagined possible. The street was studded with men's cheap clothing shops, pawn-brokers' stores, nauseating restaurants and other similar establishments. Most of the vendors displayed their wares on the sidewalks. I hadn't proceeded twenty feet before a high-pressure, stout proprietor of one of the clothing emporiums had caught me by the shoulder, and by actual physical force, had pulled me into his store. Before I knew it, I had my coat off and was being pushed into one I was supposed to be buying. I hadn't had time to think until this point, so fast had he "operated." I called upon a bit of applied psychology, told him between jabs I wasn't in the market for any clothing today and began removing the coat while I explained that I was looking for McGill University, and if he could direct me there, perhaps I would call back a little later in regard to some clothing. He held up both his hands. "Oh! McGill University! She's on Mount de Royal. She's long ways off." (p.35)

Ninety years later, McGill students now flock ten blocks east to St. Lawrence - the smelly grocery shops have turned into trendy bars and cybercafes.

\section{STRATHCONA HALL}

Trott finally arrives at McGill. Someone advises him to spend his first night at Strathcona Hall, on Sherbrooke Street across from McGill. Run by the YMCA, this was McGill's only residence for men (women had the lavishly appointed Royal Victoria College). Besides three floors of bedrooms, Strathcona Hall had lobbies, a reading room, auditorium, and club rooms. ${ }^{4}$ McGill's Calendar for Trott's first year, 19181919, warned that board and lodging in rooming houses near McGill cost at least $\$ 40$ per month, although Trott may have got by more cheaply. Tuition for medical students came to $\$ 147$. With annual board and lodging at $\$ 310$ to $\$ 380$, medical books and instruments at $\$ 53$ to $\$ 63$, and Union and athletic fees at $\$ 10$, and incidentals, a medical student like Trott would need around $\$ 550$ to $\$ 650$ a year. $^{5}$ 
At Strathcona Hall, Trott meets other medical students, who make up a large portion of the residents. Indeed, all the students mentioned in Campus Shadows are fellow medical students. Trott did not join a fraternity or clubs, had no connections in Montreal, and accordingly drew his friends from his faculty and places of residence. Trott singles out Lester Michael, from a Nova Scotian fishing family, who has saved $\$ 380$ from his share of the catches to cover his expenses. Lester Michael does not appear in the directories of students and graduates. ${ }^{6} \mathrm{He}$ may have attended so briefly (one year) or registered so irregularly that his name was not recorded. Or Trott may have invented him or extrapolated him from one or more real students. This "ghost" would undermine the believability of the memoir except that Michael is the only McGill student or staff member named by Trott who is not to be found in the Directories of Students, the McGill Calendars and student annual Old McGills. The others existed. Another frequently mentioned friend, "Bobby Waite," was almost certainly F. Elmer Wait (M.D.C.M. 1923). ${ }^{7}$ And nearly all the other medical students Trott names, including Qui Hin Chan, Louis Chadsey, Victor Mader, John Demaray, Horace Jessup, George Harkin, [Norman] Higinbotham, Harold Mayer and $\mathrm{H}$ [orace].O. Wilson can be verified as having been students in Trott's time; they were listed in the annually published Directories of Students (1918-19 to 1925-26) and, except for Harkin, in the cumulative Directory of Graduates (1946). Though death or oversight kept him out of the 1946 Directory of Graduates, Harkin, like Trott's other friends, did indeed graduate (in his case 1921). ${ }^{8}$ All this supports the truthfulness of Trott's sometimes novelistic memoir.

Surprisingly, Trott says nothing about the influenza epidemic of 1918. The McGill term started at the beginning of October 1918 and the McGill Daily reported the usual announcements and events. However, on 8 October by order of the Board of Health, McGill was closed and classes cancelled because of the influenza danger.
Just after the Armistice of 11 November 1918, the McGill Daily of 13 November trumpeted that the flu was over and the McGill Union open again. A sign of the times, it also listed newly banned communist newspapers - and inevitably Trott would acquire the nickname Trotsky. On 16 November, the Daily noted that the students were back after six weeks of holidays, that lectures would begin on 18 November, and that medical students, including the first-years, had helped in the hospitals. It is not clear if Trott was among them. The Daily declared that with the war over, students were reviving university activities enthusiastically and that that the outlook would be improved by the return of a large group of medical students from the war front. ${ }^{9}$

\section{CAMPUS TOUR}

Trott and Lester Michael decide to stay at Strathcona Hall until they can find a cheaper boarding house. The next day, they tour McGill's campus. Trott observes that "McGill's grounds were, and still are, beautiful - old and stately buildings, personification of stability and solidity. For years they have symbolized all that is learned and upright in Canada." (p.39) McGill owed most of its physical plant and endowments not to government support but to capitalist benefactors, notably Peter Redpath, Sir William Macdonald and Donald Smith (Lord Strathcona). Like most visitors, Trott admires the Engineering, Physics, and Chemistry buildings given by Macdonald as well as the Redpath Museum and Redpath Library, all built in Montreal's signature grey stone. Naturally, he is most interested by the new Strathcona Medical Building (opened in 1911): "It was impressive. Well-equipped and completely up to date, it was at that time the pride of the University." Its museum fascinated Trott, especially the pathological specimens: "Small embryos in uteri, specimens of babies with extra legs or arms, and one particular specimen with two heads." (p.40) Trott's campus description closely resembles that of Dink Carroll's fictional 1920s student Peter Rice, who 
described the science buildings as coming from a great tobacco fortune, the museum from a sugar fortune, and observed: "The city's capitalists had given both money and affection in large gobs to the university." 10

Returning to Strathcona Hall, Trott unpacks his trunk and puts up two framed gifts from his friend Elizabeth, a school teacher. One is an inspirational verse by Edgar Guest, the other a verse by Louise McGrath, "For Him", illustrated by a teenaged girl praying beside her bed in a nightgown. Trott found both verses "alive with courage and inspiration. I never walked into that room thereafter without being as conscious of them as I would have been of another person." (p.41) These simple icons would help him survive the trials ahead.

\section{AN INTERESTING ROOMING HOUSE}

Neither Lester nor'Trott can afford fancy lodgings. They fear rooms without meals at Strathcona Hall will be too expensive at $\$ 20$ a month. Most McGill students who did not live at home lived in boarding houses, which provided meals as well as rooms. These were old row houses to the east and south of the campus, built from the 1870s to the 1890s for prosperous, middle class families. By the 1920s, as these families moved to the west of the city, their homes became rooming houses and flats. (They would be resurrected in the 1970 s as heritage condominiums, co-ops and townhouses.)

Near McGill, Trott and Lester see a "Rooms for rent" sign. The door is opened by "a very thin, stately looking lady in a black dress and high collar." In a hall they pass a girl in a dressing gown:

"And how much," [Trott asked], "do you charge for the rooms?"

There was a moment of hesitation. Then the proprietress replied,

"Well, now, that all depends. Would you boys like your rooms with or without?"
"With or without? With or without what?" I enquired.

She folded her arms, brought up her shoulders at least a degree higher and in a crisp, business-like tone informed us, "Well, boys, you see we have some very attractive young ladies living here who work as stenographers or at other office positions. Many of them don't receive as much pay as they should be getting these days, and if you would like to share a room with one of these girls you can have a room for six dollars a week. In addition to this, the girl pays only one dollar." (p.42)

They flee. Perhaps the story is exaggerated, perhaps not.

\section{OUT OF POCKET}

Disaster strikes. The cheque drawn on Trott's bank at Melrose, Ontario is no good; the bank has just failed [such failures were rare in Canadian banking]. Trott returns to his room crushed, fearing his medical career is finished. He looks at the framed poem by Edgar Guest:

No one is beat 'til he quits,

No one is through 'til he stops. (p.47)

The picture of the girl kneeling in prayer also inspires him. He draws up a battle plan. He gets his McGill fee deadline extended a few weeks. Now he must find paid work and quickly. He goes to the popular Child's Restaurant, sees the manager, and makes a deal to work three hours a day in return for meals - an hour each in the rush times of breakfast, lunch and supper. His eating problem solved, he places an advertisement in a newspaper: "UNIVERSITY STUDENT MUST HAVE, AT ONCE, WORK FOR SUNDAYS AND NIGHTS, CAN DO ANYTHING." (p.50) Next day he gets offered jobs in two private homes, stoking furnaces and shoveling sidewalks after snowfall in return for lodging and cash. He sublets the rooms with part 
of the stoking duties to other students and so is able to keep on at Strathcona Hall with his friend Lester. But he still has the back-breaking job of clearing snow in Montreal winters and needs to use a shovel; he had hoped a broom would do the job! He must delay paying his school fees; he is assured by the Dean's secretary Miss Mary Brand, "friend to every medical student of her time that she would square things for him." (p.54) Mary Brand, who would die of cancer in 1923, and her successor Gertrude Mudge were beloved by generations of medical students. ${ }^{11}$ Trott and Lester Michael get other odd jobs. By late fall, Trott's earnings exceed his expenses. (pp.51-55)

\section{FIRST INITIATION:}

\section{NOVEMBER $1918^{12}$}

Hazing of freshmen at McGill followed the North American pattern; on the rise by the 1890 s, dying out in the 1960s, although jovial traces survive to this day in "Frosh Week" activities. Trott described his rougher freshmen initiations at length. Traditionally the sophomores, the second year students, fought the new students in a pitched battle known as the "Rush." If the second year won (and they usually did), they humiliated their prisoners in various ways, tying them up and leading them through the streets. On 16 May 1918, the Corporation of McGill (arbiter of academic policy and precursor to McGill's Senate) had banned the organized kidnapping or other violent or objectionable proceedings practised by the first and second year men against one another. ${ }^{13}$ On 13 November 1918, the McGill Daily's editorial, "The Last of the Rush," declared that the ancient conflict between the first and second years had ended, given its death blow by Corporation's decision and by the suspension of all activity during the influenza closing. Besides, added the editorial, "the Freshmen, having had far more time for organization than is usually the case, are likely to prove all the more formidable this year. ${ }^{14}$ Furthermore, the Rush with its egg battles would seem trivial in view of the Great
War just ended with its real grenades and bombs; the returning soldiers would hardly approve the spectacle of students mimicking the real battles they had gone through! It would, however, have taken more than a World War and the McGill Corporation to end this rite of passage overnight. Six days later, the axe fell on Trott and his friends.

Trott's account of the first of two initiations he underwent may be compared with the McGill Daily story of 20 November 1918. Trott's had more detail; they agree on the main events. According to Trott, the first year students in Strathcona Hall were notified one evening that they were invited to a pajama party. At 11:30 pm., on 19 November, about 80 sophomores crowded up the stairs to the bedrooms. They outnumbered the 30 freshmen. The freshmen were told they were going on parade and that this was not the main initiation of freshmen, still to come, but merely an initiation into Strathcona Hall - "just a little get-together." (p.57) The Daily account had them taken by surprise: "In response to polite taps upon the doors, the frosh invariably got up out of bed and pulled back the bolts allowing an easy access to their rooms." According to the Daily, they put their pajamas on over their street clothes; then their faces were painted with various colours: Many an innocent who had yet a downy fluff on his cheeks was suddenly adorned with a huge military moustache and chin whiskers." 15 They were tied up in a line as well.

Then the sophomores sold the freshmen safety pins to keep their pajamas fastened and forced them to parade to St. Catherine Street, carrying a banner with the words: "LOOK US OVER GIRLS. IN FIVE MORE YEARS WE'LL BE READY" (pp.58-59) The "Five Years" implies they were all taking the medical program. They stopped on McGill College Street and were taught the freshman yell, added the Daily. ${ }^{16}$ Trott recalled that at $\mathrm{St}$. Catherine Street they had to parade around the traffic officer on duty and that the cop took their Maypole act and stoppage of traffic with good nature. The police seldom 
interfered and consequently the students had a warm spot for them. Next, they were herded to the "Jardin de Danse." Here the sophomores bartered with the ticket office: "Eventually the manager came to the street accompanied by what must have been half the police force of Montreal." (p.59) A bargain was struck; the students were to stay for one hour only and deposit $\$ 50$ for breakage. The victims were told to get girls and dance. That was not always easy: "You couldn't blame the girls for feeling a little self-conscious about dancing with a pack of sheepish freshmen in pajamas held together in the front with safety pins! Gradually they broke down, however..." (p.59) The Daily added that the freshmen had to sing songs such as "It's a long way to Tipperary."

Next they had to commandeer a tramway car and make it take them to the "Palais de Danse" further east towards St. Lawrence Street. At this establishment, they were refused admission; at the entrance "two guards stood by and manned the gates with drawn revolvers." (p.60) By now allies, the sophomores and freshmen rushed the doormen - in the scuffle Lester got hold of one of the guns. He kept it as a souvenir; later they found it was unloaded. The manager, "with profuse gesticulations and a French vocabulary that was amazing," called the police, who came but did nothing. When the manager told the orchestra not to play, the students commandeered the instruments. Trott observed, "Nobody got hurt, but in the scuffle, one of the sophomores unfortunately deposited his foot inside the bass drum. The harpist agreed to play even though it cost him his job. That would still be better than having his harp broken." (p.61) Trott claimed that the patrons enjoyed the diversion and that the orchestra forgave them for using their instruments. Then everyone marched to the Ritz Carlton, where the freshmen took over the shoeshine parlour to shine the sophomores' shoes. Next they paid for the sophomores' dinner at a nearby restaurant, standing at attention while the sophomores ate. The Daily added that before returning to Strathcona Hall, they stopped and serenaded the girls in Royal Victoria College the girls' white forms appeared at the windows. At $3 \mathrm{am}$. the men all returned to Strathcona Hall and shook hands all around. Trott concluded: "All inter-class animosity was forgotten in that moment and not one of us would have missed any part of the evening for three times the cost." (p.62) The freshmen had paid for meals, safety pins and perhaps breakage. Relieved this first hazing was over, Trott, like most students, appears to have felt no great indignation at the custom; in fact, in most such initiations, persecutors and victims colluded.

\section{BULL SESSIONS, THE INCOMPARABLE CHAN \& AN OPIUM DEN}

Life in Strathcona Hall was lively; there were 34 men, occupying 22 rooms. Many were medical students and the discussions were free-wheeling:

the heated arguments we had over religion, the slave question, the Irish question, the cause of the Civil War, the advantages and disadvantages of Canada being annexed to the British Empire, marriage, sex, infidelity, prostitution, fame, and the yellow-race situation were such that I felt that, if I ever came to the eve of my graduation, I would be fully as capable of conducting a honeymoon in Shanghai as I would be of removing an appendix or treating a serious case of pneumonia. (pp.54-55)

A Chinese student moves into Strathcona Hall and registers in medicine. Qui Hin Chan, who would graduate in 1925, was born in Vancouver but educated in China. He speaks English well. Trott finds him sophisticated and engaging: "Calm and consistent in every action, slow to speak and very deliberate." (p.63) With Chan's photograph in Old McGill (1924) is his favorite expression - "Soak the rich and help the sick."17 Trott relates verbatim, in novelist's style, a long matrimonial discussion among his medical 
student friends. Chan declares that in China they are more honest about the difference between love and sex appeal; that Americans think they marry for love but it is really for sexual attraction. "We in China are more honest." A Chinese man married a woman because "he liked the shape of her ankles, the lines of her body. He married her because he thought he'd like sleeping with her." (p.64) Another student [Norman Higinbotham] rebuts Chan: "marriage is a business proposition and any darned fool, who marries a girl just because her sex appeal creates a biologic urge, is crazy." (p.64) Harold Mayer declares: "That's not what love means. I mean real love. There is such a thing and I think most of you know it, though for the sake of your argument you choose to ignore it. There is little or no connection between love and ordinary sex appeal, I know." (p.64) Bill Jones ${ }^{18}$ opts for practicality: "As far as I'm concerned, when and if I ever get married, I'm going to look around for a girl who can cook, keep house, raise a bunch of kids, play bridge and maybe a good game of poker once in a while - make contacts to increase my practice. In short, I'll find a business partner, who is willing to help me attain the things that neither could have alone." (pp.65) Vic Mader concludes: "The whole debate is almost pointless. Nobody here can deny that marriage embraces sex appeal, love, self-promotion and all the other things ascribed to it. Where the boundaries fall that mark one from another is a question that won't be decided in a room in Strathcona Hall." (p.65) Chan surprises everyone by revealing that he has been married for three years and has three children.

Chan educates his friends. He takes them out to a restaurant in Montreal's Chinatown and is amused by their attempts to use chop-sticks. Then he shows them through an opium den:

That night my eyes looked upon splendor and extravagant, oriental luxury such as I shall never see again; and I saw the most horrible, nauseating, soddenlooking lot of human derelicts I had ever imagined existed. It was scarcely to be believed that such human wrecks... could actually remain alive. They lay on beds built like berths in a train, three high, one above the other, each occupant with his inseparable opium pipe.... So labyrinthine were the stairways and halls by which we travelled, that I should never be able to find these opium dens again. (p.67)

Trott believed the friend he called "the incomparable Chan" may have later become a health officer in Hong Kong.

\section{MEDICAL STUDIES}

The first task of Trott's lab work at McGill was to dissect a worm. Soon he went on to cadavers, after a lecture on technique by Dr. [A.E.] Orr, lecturer in anatomy. Some of Trott's very broad training in general clinics and ranging from obstetrics to mental disease will be noted later. Here, his description of learning anatomy through long hours of dissecting a cadaver may serve as a sample of his early courses:

A student is required to dissect away every globule of fat and interstitial tissue, to separate and define each nerve, bloodvessel, tendon, muscle, valve, organ, bony prominence and sinew. This is to afford him a complete understanding of the physiology, histology, and pathology of the human body and to build a solid base of the fundamentals on which he must depend... whether it be in the field of medicine or surgery....

A student doesn't usually enjoy his first meal after the initial dissecting room experience. Within a week, however, we were able to discard the dissecting-room from our minds the minute we walked out of its doors to go to lunch. After all, what is dirt and decay except matter out of place? With a little practice in mental control, we were soon able to 
discuss a special bit of fine isolation of the foramen ovule, or the anterior striate branch of the middle cerebral artery, the while enjoying a juicy steak. (pp.71-72)

For aesthetic and practical reasons, students hated fat cadavers, whose fat had to be dissected carefully away before the structures may be isolated and studied. However for those occasions when students become obstreperous and a little "pitching contest" gets under way, those with fat cadavers have more ammunition. (p.72)

Much of the teaching went on at McGill's affiliated hospitals. The grand Scots baronial Royal Victoria Hospital (RVH) was just up the hill from McGill. The plainer, older Montreal General Hospital (MGH) was in a grittier downtown location. Trott had the small-town boy's fascination with the good and evil he found in Montreal and was put off by the seamy scenes on the way to the General:

To walk down Cadieux Street (which is beside the Montreal General Hospital's back door, where the medical students pass each day for lectures) will produce a whore hanging out of every window doing her best to call you in for fifty cents or a bottle of gin. It will send you home nauseated with shocking tales of crime and prostitution that will cause you to send your boy to medical school in some white-faced, Godly city where chapel is held each morning in the students' lobby - and modern girls enter by way of the basement each night, instead of hanging out of second-story windows. (p.76)

This was partly tongue-in-cheek. Trott's own son Edward later attended McGill's medical school (M.D., C.M. 1963) and Trott, like Dink Carroll and most others writing about McGill, realized that the University was indivisible from Montreal - for better or for worse - mostly for better.

\section{SECOND INITIATION: 14 DECEMBER 1918}

Rushes and hazing thrived and waned in the 1920s and 1930s as the University's administrators sailed a course between toleration and suppression - student pressure reduced hazing by around 1927. Some thought that such outbursts, like sports, prepared men for the battles of life and war. Others did not. In 1924, the year Trott would graduate, Physics Professor Howard T. Barnes voiced his concern to Principal Sir Arthur Currie that the old style rushes were returning to campus and among other evils might turn students away from McGill; he related his own past efforts to replace skirmishes around his Physics Building with athletic contests. ${ }^{19}$ Not all disturbances revolved around hazing. Exuberant McGill students stopped traffic, rallied before football games, and threw garbage at Theatre Nights. They provoked such reactions as that of a "Disgusted Graduate" who wrote to the Daily on 13 December 1918 deploring "the disgraceful spectacle of a gang of students parading the street [giving the McGill yell].... such an exhibition of bad taste as this can only serve to bring disgrace to Old McGill."20

As if to provoke its readers, on 6 December 1918, the Daily published a snapshot of students in the Rush of 1914 captioned "Is It Gone Forever?"21 So far, initiation of the freshmen by their faculties (Arts, Medicine, Law, Applied Science) had not yet taken place. By custom, freshman of each faculty gave a dinner every year to the sophomores. Traditionally the roughhouse initiations preceded the friendlier dinners. Trott noted that since the year had begun late because of the flu, by December there seemed a chance the sophomores would forego initiation. Some dinners were given; the Arts freshmen dined the sophomores at the Ritz on 10 December, where, ominously, one speaker "deplored the passing of the one time 'rush' that had been one of the freshmen's introduction to McGill." ${ }^{22}$ 
The freshmen's hope for reprieve was shortlived. Trott's account conveys the thrill of battle, but he is vague on detail and is supplemented here by the Daily account, written, inevitably, in the humorous style of college journalism of the day. The rush probably involved only medical students. It took place on Saturday, 14 December 1918 when, as Trott recalled, about half the medical students were in the biology labs at the north part of campus and the others were in the Chemistry Building. The students in both locations were attacked. In its story titled "Great Doings in Rain on Saturday A.M. - Embryo Meds. Enjoy Novel Slush Bath Many Casualties," the Daily enthused that "On Saturday morning perhaps the greatest battle which has been fought since the signing of the armistice took place.... Suddenly about 11 a.m., some inquisitive frosh in the biology lab made the ghastly discovery that their building was surrounded by a mob..."

Scores of figures clad in sweaters and caps were seen forming a complete circle about the building. Pandemonium reigned in the ranks of the Embryos.... the remaining cohorts, calmly carving holes in dogfish in the Zoology department became aware that they, too, were surrounded. Scalpels were dropped and terror was registered in every eye. ${ }^{23}$

The students at the Macdonald Chemistry Building were also surrounded. Students in both buildings came out to do battle but were overwhelmed. The Daily continued:

A wild mass of arms and legs, rolling in many centimetres of soft slush, is the most appropriate way of describing it. The next scene was a long line of verdant ones marching off with hands securely fastened behind their backs and florid faces adorned with many brands of shoe polish. ${ }^{24}$

The techniques of tying up and applying shoe polish differed little from the earlier attack on the
Strathcona Hall freshmen. Things got rougher this time, as Trott remembered - after all it was not just hazing but a battle:

I had tackled a fellow about my own size. Having had a bit of wrestling experience, I managed to get him all tied up with his trouser braces and belt, when he exclaimed, "Why you're a freshman, you darned fool! So am I! Untie me!" Chagrined and apologetic, I freed him. In less than two minutes, he and another sophomore had me all wrapped up like a Christmas gift. (p.74)

Trott laid his class's defeat to the fact that they did not yet know all their classmates and were disorganised."Freshmen can't win," he concluded. "We got the full force of the rotten eggs, and then were bowled over by the streams from the firehoses." (p.74) The Daily finished the story. The humiliated freshmen had to parade in front of the fair female students of Royal Victoria College, then march downtown to Phillips Square, where all disbanded. Coyly, the Daily concluded that there was no definite information as to the identity of the "miscreants" who carried out the attack. After all, such rushes had been banned by the McGill authorities! And on the following Tuesday, the medical freshmen dutifully dined the medical sophomores - no hard feelings were reported. ${ }^{25}$

This initiation was rough but no one got killed. Afterwards, Joe, the one-eyed janitor ${ }^{26}$ at Strathcona Hall assured Trott and his bedraggled classmates that "Initiations ain't what they used ta be!" He reminisced about one in which fighting got out of hand:

The police were involved in the fracas. The sophomores soon felt the necessity to untie the freshmen to augment their own forces in fighting with the cops. Girls from [Royal] Victoria College [McGill's women's college] entered into the fray throwing mud, stones and "what have you" and the battle was in dead 
earnest. Janitors and even laboratory technicians got into it. The crowning tribute was the fact that even a professor was accused later of joining forces with the students. (p.75)

To top it off, the French students from Laval's Montreal campus - who normally never mixed with McGill students - heard about the fight and came to McGill's campus to help their McGill confreres fight the police. According to the janitor (possibly named Joe Wilcox) who told Trott the (unverifiable) story, two policemen and one student died from injuries. The janitor said he had lost his left eye when struck by a badly aimed piece of brick thrown by a Royal Victoria College girl at a policeman. "Oh, but it was a great fight," Joe reminisced. "We tied them cops all up in a knot before we was through and I wouldn't 'a' missed it f'r anythin.' (p.75) Whether or not McGill had Canada's best students and professors, it may have had the most sympathetic janitors and building superintendents. In the 1920s, Bill Gentleman, everyone's friend, reigned in the Arts Building, along with Harry Barker, who quoted Shakespeare and wrote verse. Harry Grimsdale looked after Engineering, and Wilcox, Law. As E.H. Collard documented in his The McGill You Knew (1975), students long remembered these fatherly figures as friends and founts of news and advice. $^{27}$

The Medical Faculty's first janitor "King Cook" supposedly had helped the students hide bodies for secret dissections at night. No medical student's memoir would be complete without a reference to the Faculty's most peculiar institution, the ceremony of crowning "King Cook." ${ }^{28}$ Cook's successors, all christened Cook, were feted each year and given money - sometimes, according to Trott, $\$ 25$ in pennies buried in a molasses barrel. Coronations involved a night of carousing, attended by medical students and the braver of their professors. Run by the senior class, it was given over to ridiculing the professors and putting on skits and songs. In Trott's first year, the final number gives an idea of the rest: "a piano duet by the Rhoea Sisters - (Gonor and Diar) - following which we sang 'God Save the King."' (p.77) The McGill Daily filled out Trott's description of the crowning of King Cook III, in real life, William Tobin. The Daily gave a florid history of past King Cook events, noting that the upcoming April First (1919) celebration would be the last to allow non-medical students to attend,"for, with the war over, pre-war conditions will return to McGill, and this pageant will once more become the unique ceremony of the medicos." ${ }^{29}$ On the great day, it was announced the procession in honour of Cook would start and finish at the Union that night after marching along Sherbrooke and St. Catherine Streets. There would be a Royal Guard, followed by Cook the Third, His Trusty Henchmen, and the medicine classes of '22 and '23 [Trott at this time expected to graduate in 1923]. Cheered the Daily: "We are back to the piping days of peace.... Lots of fun and lots of pep!" 30 As reported next day, Cook was crowned King of the Bolsheviks, gave a speech of nonsensical debauchery, preceded by 33 skits in his honour in the Union Hall. The skits were inspired by world affairs, and included appearances by the Czar, Czarina, Rasputin, the Kaiser goose-stepping, speeches by De Valera, Henry Ford, Trotsky, Lenin, a cannibal leader, and Montreal Mayor Martin [?]. There were dances and hymns. ${ }^{31}$ Sadly, such cultural ephemera seldom survives, except in news clippings and foggy memories.

Student dinners, initiations, and rowdy Theatre Nights often resulted in damages, especially to restaurants and dance halls. Claims arising may be traced in Principal Currie's records. A claim by Child's Restaurant (Trott's erstwhile employer) addressed to the McGill Students' Council can serve as an example, though a little after Trott's time. Following a visit by the McGill students on 10 November 1928, the total itemized claim for loss and breakage came to $\$ 297.10$. Broken objects included 36 trays, seven pepper shakers and two bottles of H.P. sauce; among items 
missing were 21 dessert forks, five dozen tea spoons and assorted cigars and cigarettes. ${ }^{32}$

\section{DEATH IN LIFE, APRIL 1919}

Trott passes his exams; he has never felt better in his life. It is April 1919 and winter is melting away. He catches a grippe but as he does this every spring, he is not worried. He begins to feel better but, ominously, feels weak in his legs. One Sunday, he sits in the sun looking out the front windows of Strathcona Hall, then goes for a campus walk with a friend, George "Harkins" [presumably George Harkin, who was in $3^{\text {rd }}$ year Medicine]. They stop for a bite at Walton's on St. Catherine Street and Trott takes pity on a crippled boy of ten, hawking newspapers in the restaurant. He buys several. When the boy finishes a doughnut left by a customer on an empty table, he is shooed out by the waiter. (Trott and Harkin met many years later and recalled the boy, whom medical advances by then could have helped.) They go back outside: "The sun was beating in all its summer splendour. Madonna-eyed girls walked the avenues with careless, insouciant grace, gaily dressed in their newest spring finery." (pp.82-83)

Trott returns to the lobby of Strathcona Hall. $\mathrm{He}$ is tired; his body seems a dead weight. He looks across to the McGill campus: "I watched the elongating shadows of the Redpath Museum and the Redpath Library as they stretched farther and farther, like tremendous giant fingers, across the beautiful lawns of the campus." (p.84) (Fig. 2) 33 The next morning, his legs give way under him. His roommate Lester and other friends call Dr. Orr, who sends him to be examined at the Royal Victoria Hospital (RVH), across Pine Avenue from the Medical Faculty. Several neurologists examine him and take blood cultures. The hours pass; his legs and now his arms feel weaker. He demands to know the worst. Dr. Colin Russel tells him what is wrong. He has Landry-GuillainBarré-Strohl Syndrome, which is an acute disease of the nervous system in which the nerves of the arms and legs stop working due to inflammation.
The cause still appears unknown. ${ }^{34}$ Trott's symptoms were progressing very quickly. Russel continued:

Either your body will recover - and if it does, it will take a long time - or you will not survive your illness.... You may expect, Trott, that within the next few hours, your arms will become as useless as your legs and presently even the muscles of your face will be affected. By tomorrow your entire body will be paralyzed.... Please try very hard to remain calm and patient. Soon you will have trouble in breathing. We have already arranged with boys of your year to help you to breathe, by pressure and release of your chest, much in the same manner as artificial respiration is administered in cases of drowning or shock. Now, my boy, if you will cooperate with us to the very best of your ability, then with the help of your fellow-students and by the grace of God Almighty, you may still come out of this. (p.88)

Trott asks if other cases have lived. No, but Russel thinks Trott will. In 1919, there was little therapy for neurological diseases. Mechanical respirators were not available. Russel's precaution of lining up classmates to help with artificial respiration was wise, although it may not have been needed in the end. Russel's honest, cautious optimism helped Trott more than anything else. It saved him from despair. Consultant in neurology at the RVH, Russel (1877-1956) was one of McGill Medicine's greats. He had become lecturer in Clinical Neurology at McGill in 1913 and would become Clinical Professor in 1922. After he died in 1956, Wilder Penfield called him "the founder of neurology in the Montreal Neurological Institute, a careful clinician, an inspiring teacher," while F.L. McNaughton's tribute included a summary of Trott's case and 


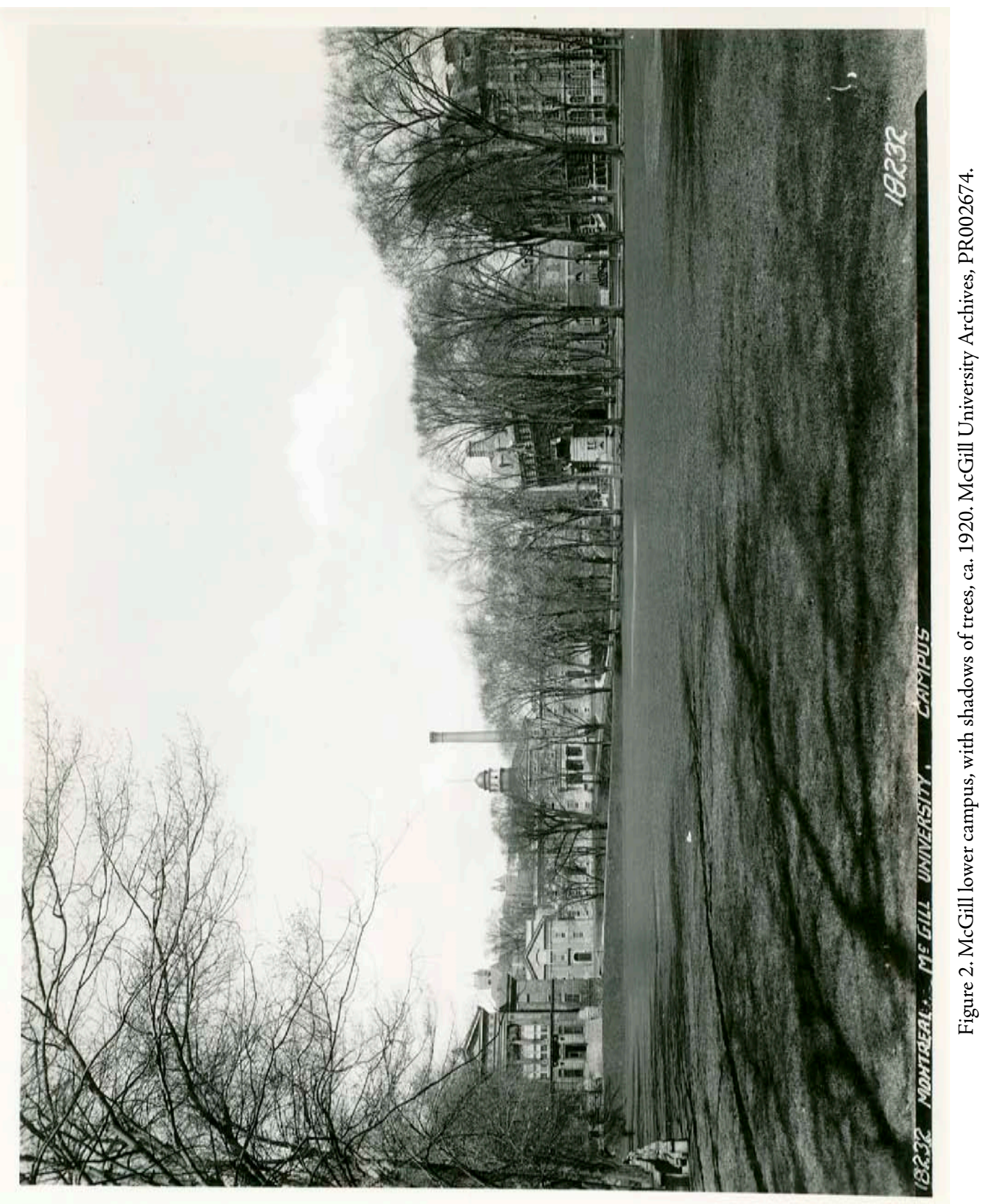


quoted Trott's appreciation of Russel from Campus Shadows. ${ }^{35}$

Trott's professors assure him he won't lose his year. Dr. Orr brings him a letter from C.F. Martin, Dean of Medicine, granting him his first year pass, even though he will not be able to take his finals. Trott realizes this is to encourage him for the ordeal ahead - "For an institution the size of McGill to take such action within twentyfour hours out of consideration for a lowly firstyear student was, and to this day remains to me, a marvel scarcely to be conceived." (p.90)

While he is still strong enough to hold a book, Trott reads what Osler's Practice of Medicine says about Landry's Paralysis. He recognizes his symptoms all too well. In the middle of the night, he wakes to realize Russel is standing by his bed. Russel says he is just passing on the way home from a party but Trott realizes Russel has gone to no party and has come in at three in the morning to check on him. There will be no passing him on to mere interns. Soon Trott can no longer talk or make any sign, even with his eyes. Russel continues to visit - he just happens to be passing - and keeps his spirit alive. He arranges for Trott's parents to visit. Although Trott loses his speech, most sensations remain normal. When he cannot breathe, Russel has him given a shot of atropine (a drug beloved of 1920s murder mystery writers such as Agatha Christie). In the following days, Trott lies fully conscious and hears the nursing staff and others talk, thinking he cannot hear. Some remark he'd be better off dead. He loses track of time. He realizes friends like Lester Michael have been visiting. His eyelids are paralyzed, his eyes dry up, and he wishes someone would close them. Over the weeks that follow, he "began to feel aware of increasing carelessness on the part of physicians and nurses alike. I couldn't blame them for despairing of my ever reviving." He wants to tell them he is still alive, still conscious. Russel makes sure Trott is constantly attended. Trott counts the time not by hours but by atropine injections.
Trott cannot praise Russel enough: "Only he, in all those long months of Hell ever really understood. He talked to me directly every time he came into the room. He stood beside my bed and spoke to me as though he knew I could hear him, as though he commanded psychic power to read my thoughts.... He told me each day I was doing fine." (p.102)

Almost imperceptibly, Trott comes back from the brink. Russel realizes Trott, recovering, is helping himself to breathe. Russel tells him: "Just hold out a few days longer now and we'll have you through it at last....we will bring you through!" Trott prays for recovery and feels that somehow this brought help. Finally, Trott can begin to communicate with Russel by rolling his eyes for yes or no. He can finally indicate he has heard all Russel's encouragement. Trott believes he is the first RVH case of Landry's Syndrome to survive. He recovers very slowly and needs crutches and braces. He is given massage therapy and electric physiotherapy at the Ross Pavilion of RVH: "Hours on end were spent in applying current to each of the hundreds of paralyzed muscles in my broken-down physical machine." (p.121) His friends give him a surprise party in the hospital for his 20th birthday, on 7 August 1919. The nurses from his ward join in - Misses Black, Parlee, McCallum, Freeze, and McDougall. He is given a birthday book signed by every house physician and nurse who had looked after him since he was admitted. Best of all, since $\$ 10$ of his tuition fee had been for hospitalization insurance, he would be billed only for medication. (pp.122-127)

From all his RVH nurses, Trott singled out a student night-nurse, Vivian Freeze, "an angel in white," who cheered him up and encouraged him for months. But her supervisor "Miss X" was a "ferret - cunning, fast, shrewd and despicable" and, as Trott points out with the male attitude of his day, "an old maid, probably about fortyfive years of age." She persecuted the young, personable Vivian for doing special favours, such as making a sandwich for a tired doctor who 
had had no time to eat. When Trott worried about involuntary contractions in his knees, Miss Freeze said it was natural. She sat on the floor with legs straight out; then as she bent forward her knees rose from the floor. "See?" she said. "All that worrying for nothing." Miss $\mathrm{X}$ caught her doing this: "The sight of a nurse sitting on the floor putting on a demonstration for the encouragement of a patient constituted nothing short of a cardinal sin." (pp.122-125) The penalties were usually additional time added to their course, thought Trott. Strict though supervision and routines were, the photographs of RVH nurses in their whites convey a striking sense of pride and elegance - more than did those of the doctors (Fig. 3, Fig. 4, Fig. 5).

Trott's recuperation had lost him a year. His classmates were into their second year and would graduate without him. In the fall of 1919, from the balcony of the RVH, Trott watched sadly as his friends went in and out of the Strathcona Medical Building on the other side of Pine Avenue (Fig. 6). They visited him but could not cheer him up. The RVH had done as much as it could; Trott was alive but his legs were crippled. At Christmas 1919, he left for home. Detouring to cross the campus, the RVH ambulance took him to the Grand Trunk's Central Station (Fig. 7). The company gave him a complimentary sleeper. And the RVH gave him batteries so he could continue galvanic electric treatments for his legs at home. Always resourceful, once home, to get around, Trott got hold of a run-down Saxon car, and repaired it to running order. (pp.128140)

\section{UNIVERSITY OF WESTERN ONTARIO, 1920 -1922}

The weakness in Trott's legs would be permanent. For the foreseeable future, he had to use crutches. It was decided that he should do his next year of medicine, starting in September 1920, closer to home and family at the University of Western Ontario, in London, Ontario, with the understanding that he would return to McGill when he became stronger. The two universities cooperated to help Trott; however, because different subjects were taken at different stages of the two curriculums, Trott had to work hard to keep up. Though not famous for medicine as McGill was, Western was establishing a strong program; its staff included Frederick Banting and J.W. Crane, a character Trott painted nearly as vividly as he did Colin Russel. In Campus Shadows, Trott often spelled out how he applied the principles of natural medicine he learned from his McGill and Western professors to his later clinical work at a New York hospital and in private general practice. Crane inspired him as no one had but Russel. Crane's lectures as professor of biochemistry, pharmacology and therapeutics influenced him powerfully: "Forget every drug in the pharmacopoeia, if you wish. Drugs are not so 'hot' anyway. But BE OBSERVANT. You can look up your drugs in a book any old time... I INSIST that you teach yourselves to be observant above all things." (p.144) Trott would carry this advice into his own practice, with a healthy scepticism towards drugs and pills.

Trott also left a brief snapshot of Banting, who was a demonstrator in anatomy and physiology at Western at the time, while carrying out experiments in Toronto. Referring to his old course notes when writing Campus Shadows, Trott found a note on Banting's lectures:

Today [no date given] Dr. Banting opined that it might be possible to afford relief in diabetic conditions by the utilization of some type of solution or extract from the pancreas of animals, which could contain sufficient pancreatic (the pancreatic secretion) so that, when given by mouth or injection, it would act in place of the normal secretion, in which the diabetic sufferer is deficient due to the condition of the diseased or worn-out pancreas. 


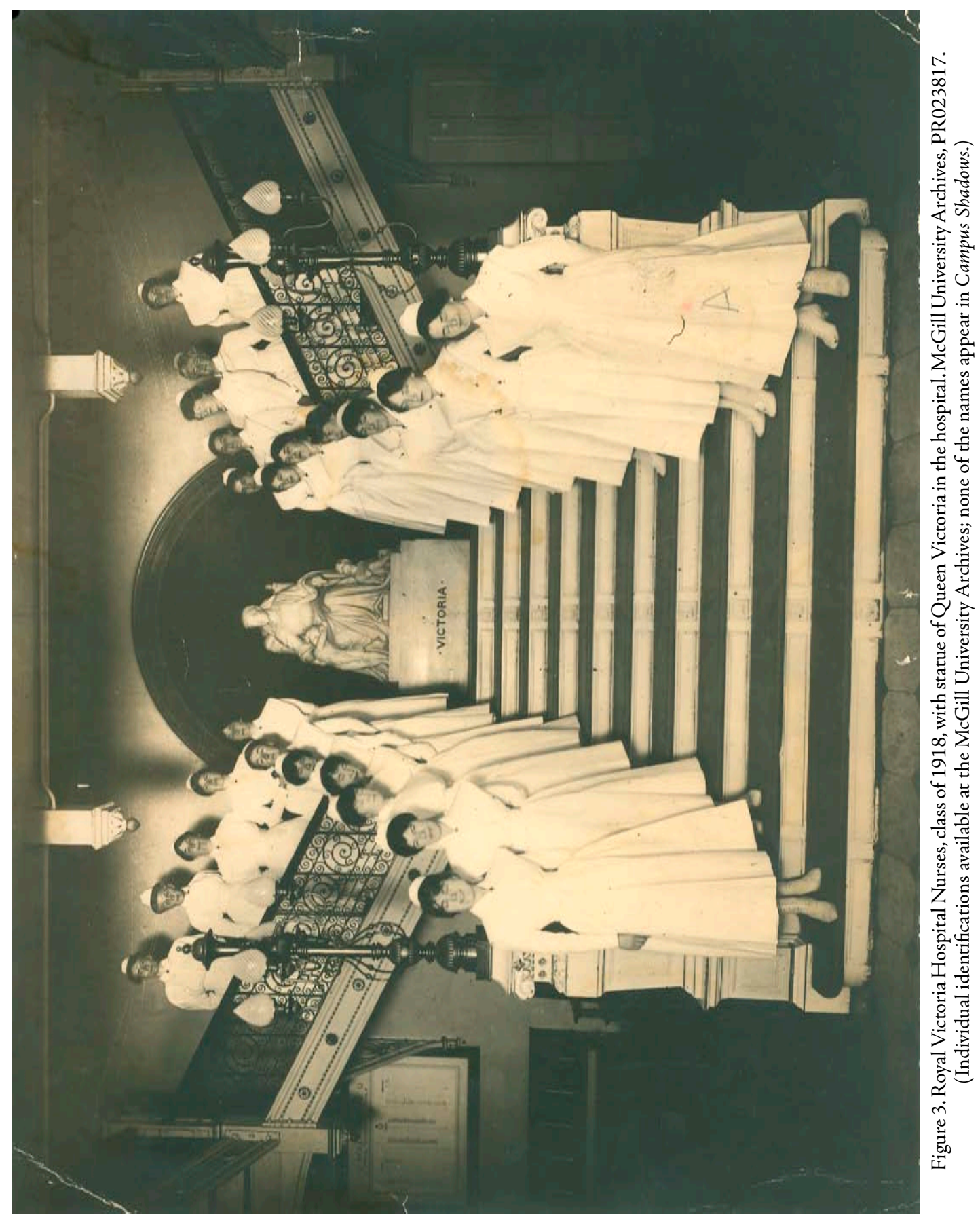


Robert H. Michel

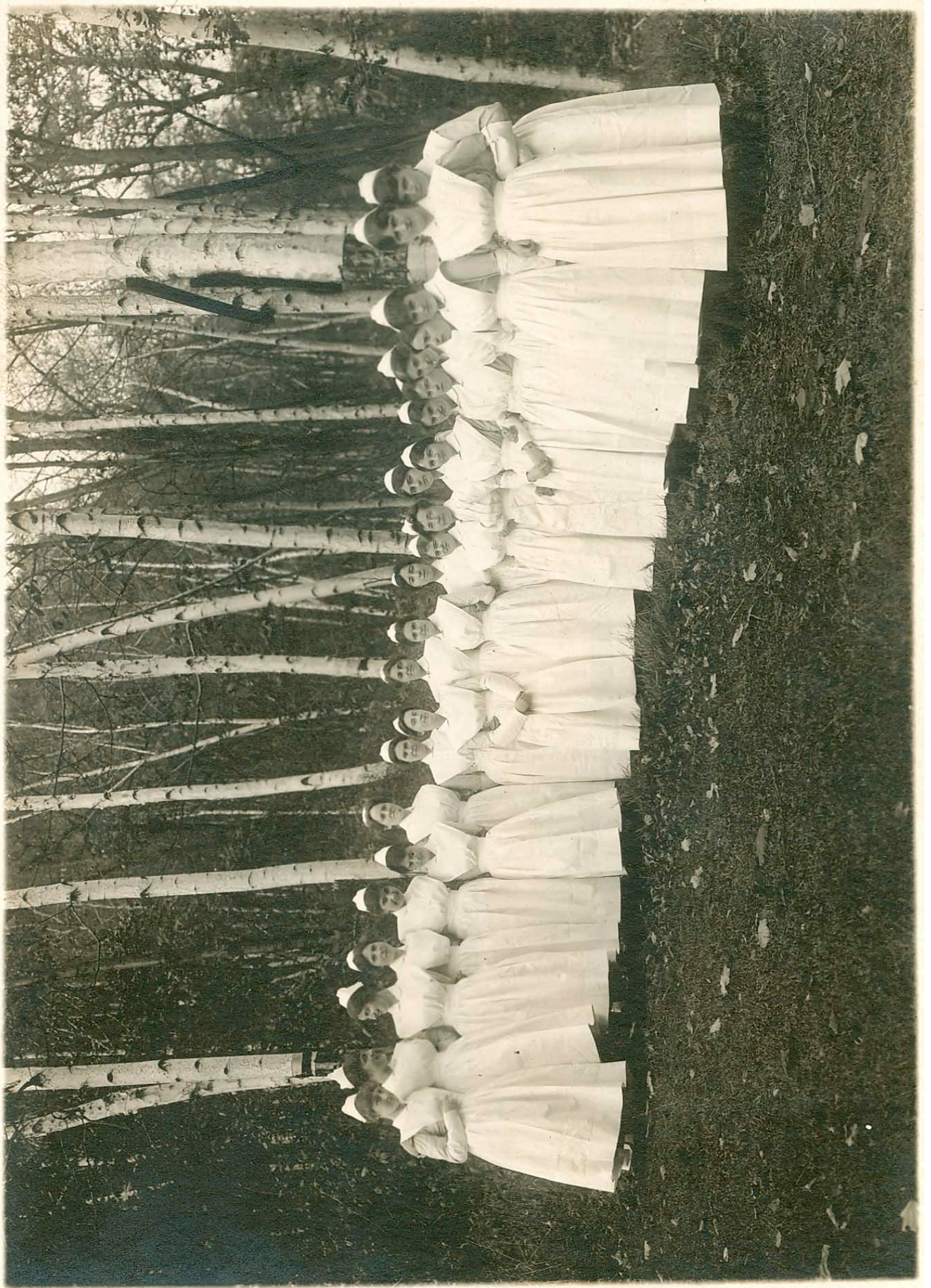






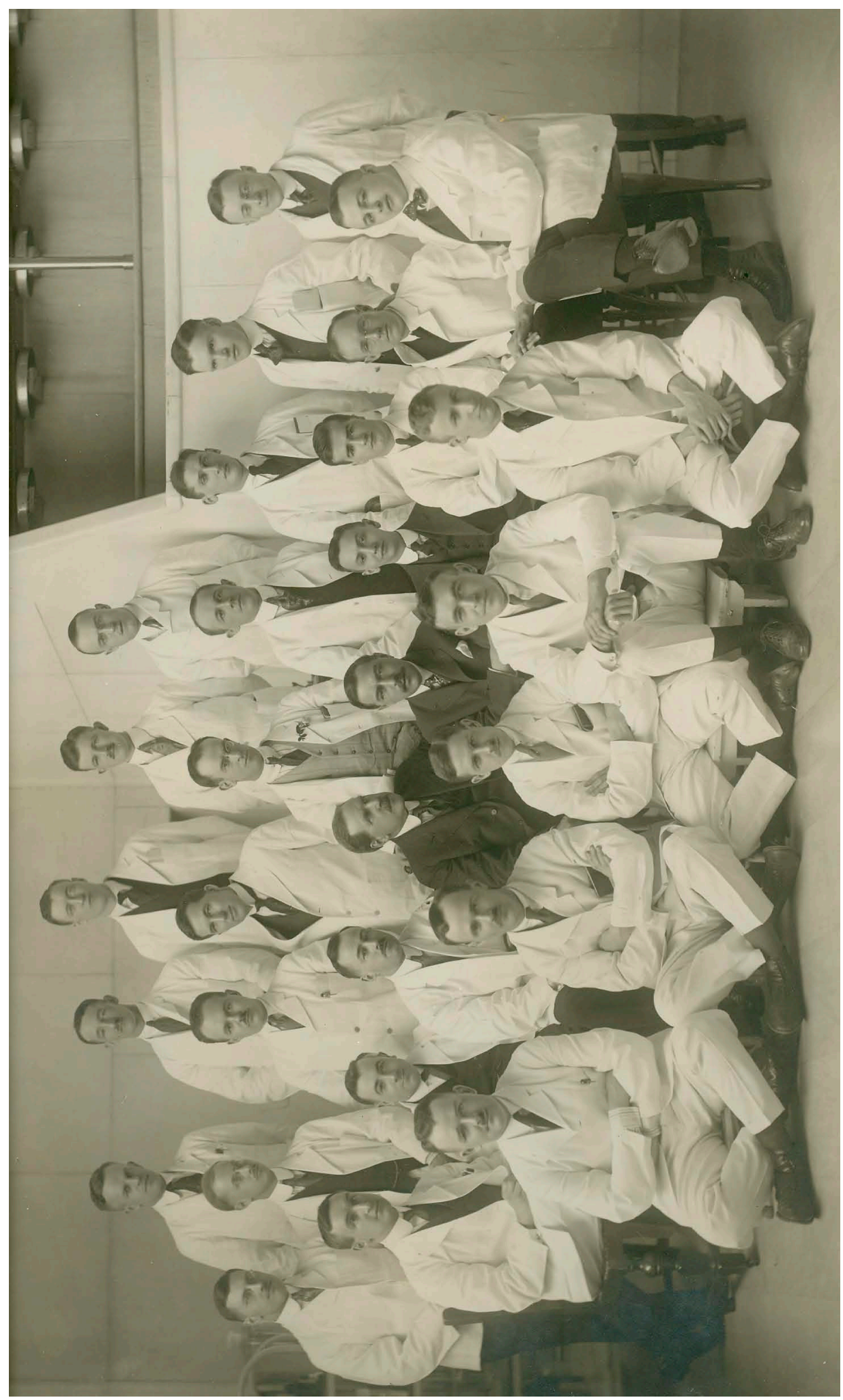









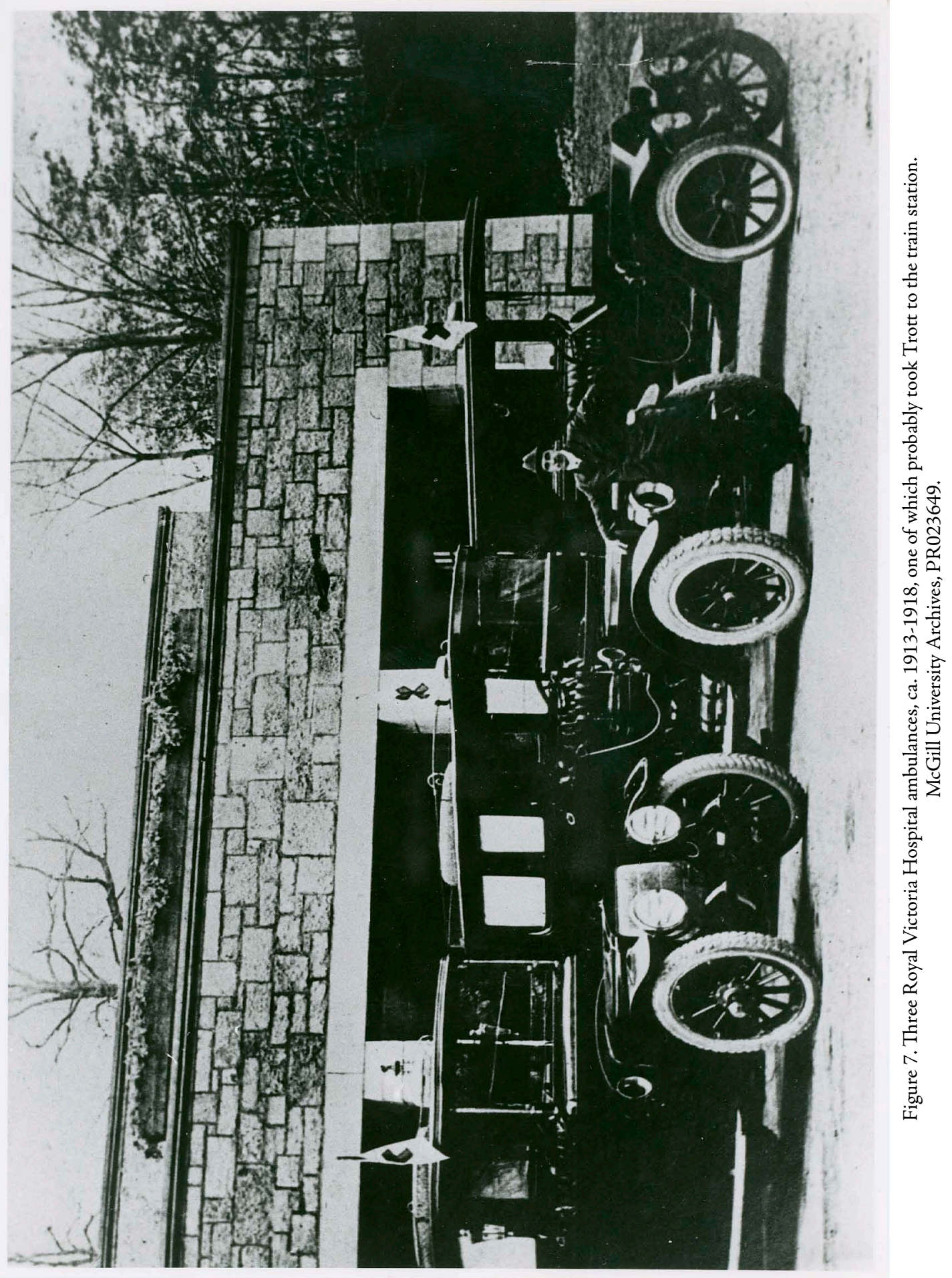


Little did I dream the day I scribbled that note, that what existed in Dr. Banting's mind that morning as a theory would one day be acclaimed by the world of medical science, an all-important discovery* (p.198)

Soon afterwards, in 1923, Banting and J.J.R. Macleod would share the Nobel Prize in Medicine for the discovery of insulin.

When many young physicians had been diverted to the war effort, medical schools finally began to make room for women. Trott left a unique portrait of Kathleen (Kae) Braithwaite, who in 1924 would become Western's first woman medical graduate. Some of the male students resented her. Many were tough, returned soldiers; they decided to give this brazen female a hard time. When the presiding doctor had to leave the dissecting room, the men began tossing pieces of human tissue at one another. Lots of the shots drifted as close as possible to Kae's table. Kae buried her head and seemed to be crying. But when the boys had run out of ammunition she struck back. "Smiles of masculine self-satisfaction were short-lived...." One of her tormenters soon felt his face "smarting from the sharp smack of a generous piece of cadaver number ten, welldirected and thrown as straight as an arrow by a tow-headed, tom-boy girl who had spent the past summer as supervisor of London's playgrounds and who had pitched baseball two hours a day the entire summer." (p.150) After a few more hits, "thrown with machine-gun accuracy," the veterans of the trenches ducked behind their tables. Then, "as nonchalantly as though she had just finished polishing her fingernails, Kae Braithwaite picked up her books, gracefully turned on her heel and sauntered casually out to the corridor, not a tear on her face, but with the faintest suggestion of a self-satisfied smile..." (p.150) From that day, she had the undying admiration of her male classmates (Fig. 8).

It was always assumed that the dissection room could be used to scare women out of medical school. A parallel may be drawn with McGill, which admitted women to medicine as partial students in 1917 and fully in 1918, the year of influenza and the war's end; the first five women graduated in 1922. Jessie Boyd (later Scriver), one of the first small group to graduate in 1922, recalled that some students declared the dissecting room was no place for ladies and petitioned that they be kept out. The faculty refused. However, there seems to have been relatively little hazing of the sort that Kae Braithwaite had to overcome, although Mary Childs (McGill M.D.,C.M. 1922) recalled spleens being thrown at women during anatomy class. Fifty years later, Jessie Boyd Scriver recalled the measures which diffused things at McGill: "For the comfort of all concerned we were ushered into the dissecting room by George Muir, the Curator, through the demonstrators' door to our dissecting table in the corner... [this let them bypass the anteroom where the male students gathered] Thus we avoided intruding upon both privacy and gaiety." ${ }^{36}$ Not all the men were pleased; the McGill Daily of 14 December 1918 published a limerick jab at Jessie Boyd, submitted by "a prominent member of Med.'22":

There was a young lady called Jessie,

Who found dissecting very messy.

Said she to me,

I wish I could be

A Doctor instead of a Freshie. ${ }^{37}$

Jessie Boyd graduated second out of 126 in her class and became a distinguished professor of pediatrics at $\mathrm{McGill}{ }^{38}$

\section{BACK TO MCGILL, 1922-1924}

Trott works the summers of 1921 and 1922 at Port Stanley as a railway gateman, then ticket seller and occasional assistant for medical emergencies; he also swims to strengthen his legs. Apropos of summer jobs for medical students, correspondence in 1920 between Dean of Medicine H.S. Birkett and Acting Principal F.D. Adams reveals that 80 percent 


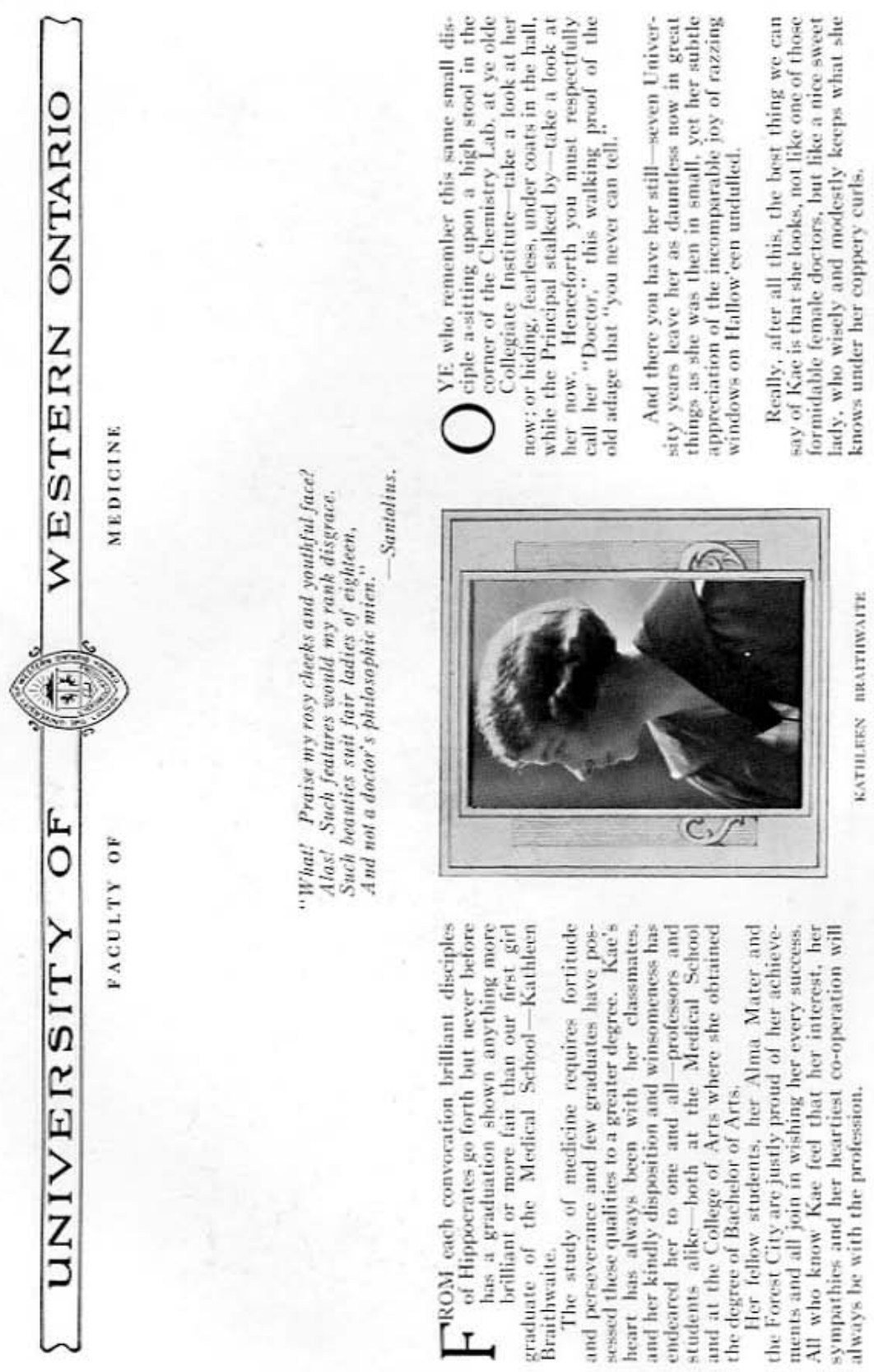


of medical students worked summers to assist them through the school year - mainly in non-medical jobs, until after their fourth year, when 50 percent found hospital work. ${ }^{39}$ With two years at Western on top of his first year at McGill, Trott returns to Montreal in Fall 1922 for his last two years. He has burned his crutches and walks with a cane. He rents his old room in Strathcona Hall for the time being. Then he visits Dr. Russel's office, balancing himself in the doorway without his cane. Before Russel can turn to see him, Trott says that he bets Russel does not remember him. But Russel remembers his voice: "I'll never forget you, Trott, but I'll be honest. I never expected to see you come walking into this office again." (p.169) They shake hands emotionally. At Strathcona Hall, Trott relives his past. He must make new friends in the medical class of 1924 (his original class of 1923 is now in its last year). He falls in with several medical students who have done their first three years of medicine under McGill-affiliated University of Alberta and whose last two years are to be done at $\mathrm{McGill} .^{40} \mathrm{He}$ hears much of one of their number, "Bobby Waite" (presumably F.E. Wait, M.D.,C.M. 1923), who has not yet arrived. Waite is legendary for being late; everyone wonders where he is. He will become a close friend of Trott's and later they will collaborate at times during their medical practices. The Alberta students and Trott resolve to seek lodgings as a group, hoping this might result in lower rates in some boarding house. They all go exploring. Horace "H.O." Wilson finds a good one. A Mrs. Down on St. Famille Street would provide room and board for seven dollars a week each. Trott's group moves in. The meals are: "stew, beans, hash, meat-pies and soups. The routine became, in fact, so standardized that we could prophesy our meals in advance for each day in the week." (p.172) The "late" Bobby Waite shows up and joins Trott's boarding house group. He is sloppy and cool. Trott assumes women must like him. But Waite is in for a fall.
There is an embarrassing episode between the male medical students and a new young woman who has just moved in. Mrs. Down had explained to her that the other boarders were all men from McGill, "but all of them very fine gentlemen." The young woman, a red-haired stenographer named Anna, moves in. H.O. Wilson is the only one to know this and apparently sets up his friends for a prank. H.O. is usually the first to use the bathroom each morning. The morning after Anna moves in, he finds it occupied and guesses it is by the new female resident. He ducks out of sight in a neighboring room (to spare her the embarrassment of seeing him in the hall when she left, so he claims later). Meanwhile, other men arrive, towels over arms, impatient to wash and get to classes on time. They bang and call at the door. No answer. Then they hear bath water running. Assuming it is H.O. Wilson being defiantly inconsiderate, they take the door off the hinges. Bobby Waite has been provided with a pail of cold water. When the door comes down, Bobby charges in, hurling the cold water: "Too late poor Bobby realized there must be some mistake. Wilson didn't have red hair and he didn't have lovely, soft, white shoulders and beautifully moulded, soft white breasts. He tried to scoop up the water in mid-air. If Bobby had been eager to get into that room, he was indescribably frantic to get out of it." (p.177) The embarrassed men replace the door at the speed of light and flee. H.O. is found nearby "in a veritable spasm of suppressed laughter." Anna finishes her bath at leisure. She becomes friendly with the landlady's daughters and takes most of her meals with them. Trott noted sadly: "Our contacts with her thereafter were very few." (p.177)

Education goes on. Trott buys a fake diamond ring (it turns out to be sapphire) from a railway porter but manages to unload it at a profit to another student; it is sold and resold. The ring finally goes to Kingston with the Queen's University rugby team, then reappears at McGill via a University of Toronto student. Trott like other students does stints in various 
hospitals, learning to diagnose diseases under the supervision of examining physicians. He comes to believe more and more that diseases are cured 90 percent by nature and 10 percent by drugs; that for most ailments (not all), the main thing is for the patient to go to bed and be given all the water he can take to cleanse the system. Trott spends the summer before his fifth and final year relaxing and building up his strength, especially in his withered legs. His muscles below the knees had atrophied since his illness. He tries to design appliances that would let him walk without using a cane. He even contemplates amputation of his legs as artificial ones would be less floppy at the feet. He tries such devices as wearing spats to cut down the flopping of his feet as he walks. He meets an old acquaintance, the attractive Gladys, but is embarrassed when he stumbles and falls while escorting her. (pp.193-196, 201-204)

Back to McGill for the final year: Mrs. Down has moved to Toronto and Trott rooms with a friend, [Louis] Chadsey. Soon they buy a piano to enliven the place. This is a year of bedside and amphitheatre clinics. At the out-patient clinic at the General, Trott takes a patient, "a girl of eighteen years, a decided blonde with large, innocent-looking eyes." Her fierce mother glares like a tiger at Trott. The mother declares her daughter has an ovarian cyst which must be removed - the mother had the same thing herself about eighteen years before. Alone with the girl, Trott examines her and becomes increasingly certain the cyst "possessed arms and legs" and had a foetal heart beat. The girl tells him she is a virgin. Trott has to report to the mother that there would be no need to operate. Wouldn't it be dangerous not to operate? asks the mother. Trott replies, "I think not. I feel it quite safe to predict that within approximately four months the - tumour - will subside. I even dare say that this is not an ovarian cyst, but a slight touch of pregnancy..." (pp.206-209) The mother whacks him with her umbrella.
Trott described a final-year lecture on "Mental Diseases of the Insane" by the man who saved his life, Colin Russel. Before Russel arrived, a small dog trotted into the lecture room. There was a box-like lectern for speakers' notes on the table at front. A student concealed the dog under the lectern; the dog kept quiet. Russel came in, put his notes on the box and declaimed on "the three most common aberrations of the mind... hallucinations, illusions, and delusions." (p.214) He gave examples of illusions: a patient might see grass waving in the wind and believe each blade of grass was a snake. Writing on the blackboard, Russel out of the corner of his eye saw the box move slightly. It happened several times more; Russel looked worried and his lecture began to falter. Finally the box travelled to the edge of the table, fell off and the dog scrambled out. After admitting he had thought he might be losing his mind, Russel carried on in good humour.

Some of Trott's clinics are at the Verdun Asylum, outside Montreal. He feels sorry for the inmates, many of whom were incurable. They have every kind of physical and mental disease. Many are in the last stage of syphilis. They come from all walks of life; some had been attorneys, business magnates, even physicians. Many of them live in the past: "daily lecturing invisible audiences, men who had been trained, cultured and useful but now, like the sad ruins of some fine old castle, once majestic and eloquent in its grandeur, now rotten, fallen, and sordid to look upon in its downfall." (p.217) One of Trott's patients, a normal looking man, introduces himself as King of the Cannibal Islands. As the year progresses, Trott goes through the letters kept by the Dean's office, offering employment in state hospitals, private institutions and similar institutions. Like some of his classmates, he gravitates to the United States. Trott is impressed by the Lee Private Hospital in Rochester, New York. The hospital is well equipped; Dr. Lee uses radium (with suitable safeguards) to cure cancer. He is also a homeopathic physician who believes in prescribing drugs sparingly - if they did no 
good, at least they did no harm. (pp.219-222) Graduation approaches. Trott recalls his class's last lecture from Dr. Walter Chipman, Professor of Obstetrics and Gynaecology. Chipman declares that he realizes the students were well versed in the procedures for difficult births, and competent in the use of forceps when needed. But he maintains that only 5 percent of cases need extreme measures or surgical intervention. In the other 95 percent of the cases doctors should not tamper with nature: To try to improve upon Nature is to presume to substitute your own judgement for a judgement that is far wiser than yours. He tells them to forget everything else they have learned and remember this: "Whenever you're called to a maternity case, LEAVE YOUR FORCEPS AT HOME. If you find that you'll need them, after all, WALK AFTER THEM, and if you have to walk after them, WALK SLOWLY" (pp.222-223)

Trott repeatedly observed that from his training and his own observations on therapeutics, natural treatments such as rest, proper diet, and physiotherapy were effective in most cases, and drugs needed in very few. (The drug industry was far less advanced and less regulated in the his time than today and doctors were right to be sceptical.) At his final lecture on therapeutics, the lecturer (unidentified) quoted Oliver Wendell Holmes's opinion "that if the entire pharmacopoeia were cast into the sea and all its drugs with it, it would be a great thing for humanity but a sad day for the fish." He told the class, according to Trott's old notes: "Remember always - there is no tonic as good as a square meal, no medicine like a drink of water, no other treatment as effective as sleep, and no physician as wise as nature." (p.224) And Trott recalled the words of Dr. Crane at Western: "Forget all you know about drugs, but BE OBSERVANT.” (p.224)

Trott graduated on 30 May 1924; his class marched from the Medical school to the Capitol Theatre to receive their diplomas (McGill having no large convocation hall). Trott took his leave in his characteristic way - solemnly, thoughtfully, and sentimentally:

Now that the time had actually come when I was to leave it for all time, I felt a reluctance to depart from this beautiful city on the slopes of old Mt. Royal. It was like parting from a fine friend. There was sadness in my heart, despite the happiness of knowing that my dreams were at last coming true. I considered how fine had been my years in this genial, old Canadian city of culture and beauty. I recalled my first days here, the lasting friendships I had formed. The long months of torture at Royal Victoria were minimized now as I considered how many and worthwhile were the excellent friendships I had earned there. Prominent among my reminiscences were the old days at Strathcona Hall. On an impulse, I went searching through my packed luggage....until I found what I sought. Placing a flat, wrapped parcel under my arm, I set out for the last time for Strathcona Hall. (pp.229-230)

The old one-eyed janitor Jim (earlier called Joe $)^{41}$ lets him in. With Jim's pass-key in hand, Trott climbs four flights of stairs to his old room. Old bull sessions waft back to him. He lets himself into his old room and unwraps his parcel. He puts his pictures of the praying girl in her nightgown and the verse by Edgar Guest in their old places on the wall. They remind him of the dark moment when he looked at them years ago when his school money was lost in the bank failure and his career seemed ended. He looks out the window and once more

watched the evening campus shadows stretch deeper and deeper across the lawns... "Here - in this spot - before this window," I mused, "I must have been presented with the understanding of what life consists, although at that moment I did not realize nor 
comprehend the meaning of what had happened. How grateful I am now that I didn't give up! And how close I came to doing so! Save for those two framed inspirations, I doubt whether I could have found the courage to meet that distressing loss."

What truer statement can be made of life than that it takes courage to meet it? And what finer thing can a man hope to possess in life than the inspirational friendships which will provide that courage?

I drew from my pocket my copy of the oath of Hippocrates. I read it - aloud and unrestrainedly. I promised to enter into the world from this room with the will and the determination to repay this magnificent institution for the learning I had received from it. I pledged myself to lead a professional life and career that would reflect credit upon my alma mater.

Slowly the sun descended into an amber west. One by one, the lights in various buildings beyond the campus began to appear. As the outlines of Royal Victoria Hospital grew dim in the gathering twilight and the windows of that great institution looked back at me in inspiring, understanding shafts of light from beyond the campus rim, I took down my poem and my picture... permitted myself one last good-bye to the glorious panorama of deep shadows and darkening lawns and descended the marble stairways for the last time to the lobby of Strathcona Hall.

As I said good-bye to old Jim, he shook his graying head and said, "Didn't I tell you, sir, that first night you came here, that I'd seen you come and I'd see you go as I had many a man before ya?" (pp.231-232)

\section{EPILOGUE}

In six years, Trott went through initiations, pranks and dissections, made friends, observed opium addiction and insanity, nearly died, and learned to live with damaged legs. His entry in Old McGill (1924, 73) nicknamed him "Trotsky," assigned him the caption: "Though college days give memories, Give me the college nights," and declared he has "unlimited initiative, and possesses an optimism of the 'never say die' type." McGill and Western trained him and ignited his thinking about medicine. Campus Shadows is a North American doctor's simple Religio Medici, with a whiff of doctors' philosophy that seems eternal. Nearly all the people and events in the memoir can be verified by other sources. Some anecdotes may have been improved in retrospect, as often happens in memoirs. But it is a good story and tells us about a McGill we will never see again. Trott's medical adventures continued in upstate New York and are related in the later chapters of Campus Shadows. According to his son Dr. Edward Trott, (McGill M.D.,C.M. 1963) after practising as a G.P. in Hemlock, New York, his father went into dermatology, practised in Rochester, and retired in 1959. Trott senior's eventful career included underwriting the building of early Piper Cub planes. He had become interested in private planes and helicopters by 1931, perhaps earlier. The Livonia Gazette, 14 September 1931, carries an article and photo of Dr. and Mrs. Trott and an "autogiro" plane, demonstrated on Trott's flying field in Hemlock. His son recalls Trott also was involved with Arthur Godfrey's acquisition of his first plane, after World War II (Fig. 9). In 1946, Trott began editing Helicopter Digest. He believed helicopters might someday replace automobiles. The Digest was published by Crosset and Williams (Hemlock, New York), Trott's own publishing company, through which he had published Campus Shadows and a children's book, Santa Claus in Santa Land (1942, second edition 1943) - the latter was written at the request of a little girl who had polio. 


\section{ACKNOWLEDGEMENTS}

Thanks for assistance ca. 2002-2006 are due Gordon Burr at the McGill University Archives as well as to Archives staff members David Poliak, Bruce Dolphin, Jean-Marc Tremblay, Mary Houde and Aaron Spreng. I am also grateful to Carol Wiens and Dr. William Feindel of the Montreal Neurological Institute and Hospital; Pamela Miller, Head, Osler Library and Christopher Lyons; Theresa Regnier, University of Western Ontario Archives, and Dr. Joseph Hanaway, historian of McGill's Medical Faculty. Also helpful have been John Hobbins and Lonnie Weatherby of Fontanus. I had useful talks with the late Dr. Martin Entin about Trott's medical case and (on the telephone) with Dr. Edward Trott, about his father's interests. Most recently Theresa Rowat, McGill University

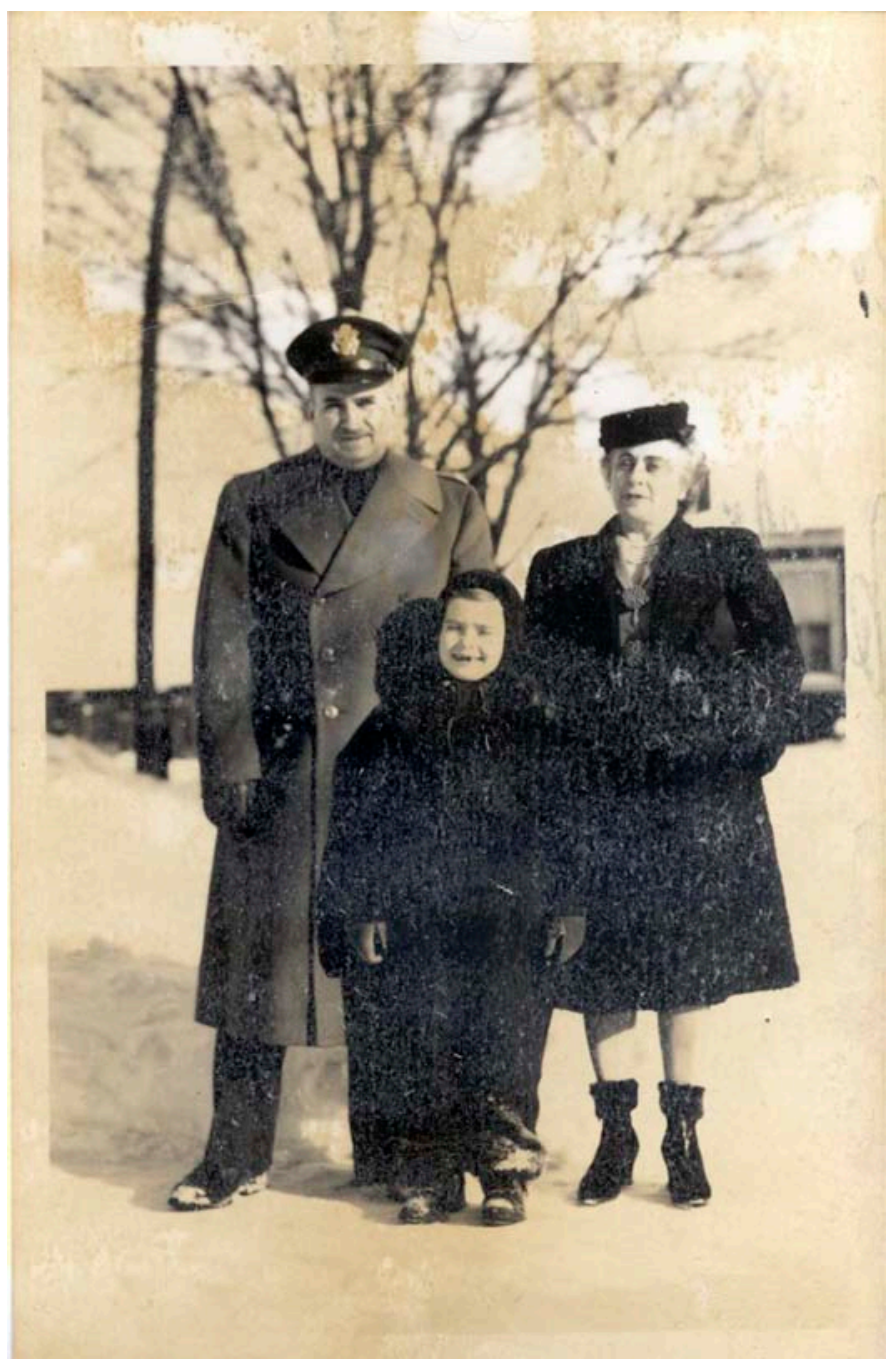

Figure 9. Mr. and Mrs. Harold Trott and son Edward, ca. 1944, snapshot which came with a copy of Campus Shadows presented by Trott to Colin Russel. McGill University Archives, Accession 2001-0160. 
Archivist has provided important information about the photographs used in the figures.

\section{ENDNOTES}

${ }^{1}$ Harold W. Trott, Campus Shadows, Crosset and Williams, Hemlock, New York, 1944, 2nd ed. 1946. Both editions have identical pagination. About 170 (or $45 \%$ ) of the 371 pages relate to Trott's years at McGill. A copy of the 1944 edition inscribed to Dr. Colin Russel, with a photograph of Trott and his wife and son, is in the McGill University Archives (Acc. 01-0160). The dust jacket of Campus Shadows was reproduced in Fontanus, IX, 1996, 82 (illustrations to Robert Michel, "Floreat Plutoria: Satirical Fiction about McGill"). Since 1862, the McGill medical degree has been Doctor of Medicine and Master of Surgery - M.D., C.M from Medicinae Doctor et Chirugiae Magister: see Stanley B. Frost, McGill University: For the Advancement of Learning, 2 vols. McGill-Queen's, Montreal, 1980-84, vol. 1, 147, n.10.

${ }^{2}$ Robert H. Michel, "The Gates of McGill: an Unpublished Novel of the 1920s by 'Dink' Carroll”, Fontanus, XI, 2003, 12-60.

${ }^{3}$ Speech, Sir Arthur Currie to Medical Faculty, 19 March 1921, typed, 12 pages, in McGill University Archives, Principals' Fonds, RG2, C67, file 1246:"Medicine - General - 1918-1926".

4 The Handbook of McGill University 1923-1924, Issued from Strathcona Hall by the Student Christian Association of McGill University, No. 34, 5. Roomers do not appear to have been subject to any religious test.

${ }^{5}$ McGill University Calendar for 1918-1919 with Pass Lists for 1917-1918, Montreal: McGill University, 1918, 71-72. Detailed descriptions of the medical courses are given, 262288. Figures are in Canadian dollars.

6 These include the annually published Directories of Students, the cumulative Directory of Graduates (1946) and Old McGill yearbooks.

7 Wait was listed in the cumulative McGill Directory of Graduates (1946). F. Elmer Wait, like "Bobby Waite," arrived after three years at University of Alberta: Old McGill (1923), 52. Bobby Waite also turns up several times during Trott's account of his practice in New York State: Campus Shadows, 294-305, 316-355, passim. Wait and Trott shared an interest in aviation.

8 These names are mentioned in Campus Shadows, mostly between pages 58 and 83 and except for George Harkin are found in McGill University, Directory of Graduates 1946 (Graduates' Society, Montreal, 1947, which lists only the 15,661 graduates believed to be alive as of 1946). All students, including Harkin, (who is listed in the Programme of Convocation: M.D.,C.M. 1921), appeared as well as in the Registers of Students compiled yearly and published with the Calendars. Most graduated M.D.,C.M. in 1923 or 1924, Chan in 1925. The "Chronicle" of Medicine 1921 in Old McGill 1921, 63, noted that in Feb. 1917 the class visited the dissecting room for the first time and that Harkin had fainted; it also describes kidnappings and street parades similar to those that Trott, who started in the Class of 1923 would go through.

${ }^{9}$ McGill Daily, 1,2,3,4,7, 8 Oct. 1918 \& 11, 13 Nov. 1918. There were no Dailys from 9 October 1918 until 11 November 1918 because McGill was closed.

${ }^{10}$ Quoted in Michel, "Gates of McGill”, Fontanus, XI, 30.

${ }^{11}$ See Peter Hanlon, “'That best Portion of a Good Woman's Life': Gertrude Mudge 1886-1958”, Fontanus, VIII, 1995, 48-57.

12 This date is inferred from press coverage.

13 Montreal Gazette, 17 May 1918: news clipping in the McGill University Scrapbook, IV, 121, McGill University Archives.

${ }^{14}$ McGill Daily, 13 Nov. 1918, 2

${ }^{15}$ McGill Daily, 20 Nov. 1918, 1.

16 "Freshies, freshies, one and all; Soothing syrup when we bawl. Good for nothing, green as grass, McGill freshies, baby class." Ibid.,1.

${ }^{17}$ Old McGill (1924), 62. The caption under Chan's name, presumably selected by himself, is "Greater love hath no man than this, that he lay down his life for his friends." The entry states Chan was educated in Canton, started education in English in 1912 and graduated from high school in Victoria, British Columbia in 1916. He received his medical degree in 1925, according to the McGill Directory of Graduates (1946), 26.

${ }^{18}$ Trott may mean Frederick Walter Jones, Med. 1923.

19 E.A. Collard, ed., The McGill You Knew, Longman Canada, 1975, 7-9; Letter, H.T. Barnes to Principal Currie, 16 Feb. 1924, McGill University Archives, Principals' Fonds, RG 2, C49, file 583 .

${ }^{20}$ Published in McGill Daily, 16 Dec. 1918, 2.

${ }^{21}$ McGill Daily, 6 Dec. 1918, 4.

${ }^{22}$ McGill Daily, 11 Dec. 1918, 1. Montreal Star, 11 Dec. 1918, news clipping in the McGill Scrapbook, IV, 141, McGill University Archives. The speaker was Marcel Gaboury, President, Arts 1922, BCL 1925.

${ }^{23}$ McGill Daily, 16 Dec. 1918 (Monday, reporting on Saturday 14 Dec. 1918), 1.

${ }^{24}$ McGill Daily, 16 Dec. 1916, 1.

${ }^{25}$ McGill Daily, 16 Dec. 1916, 2; 18 Dec. 1918, 1.

${ }^{26}$ A one-eyed man named Wilcox was janitor of the Law Faculty, located in the East Wing of the Arts Building. Whether he did a stint at Strathcona Hall is uncertain; see Collard, The McGill You Knew, 222-223. Trott could be vague about names; he called the Strathcona janitor "Joe" on p. 75 and "Jim" on p. 230 of Campus Shadows.

${ }^{27}$ Collard, The McGill You Knew, devotes a chapter to "The Students' Best Friends: The Janitors”, 216-223. Confirming McGill's enthusiasm for its janitors, Regis Messac, who 
taught in McGill's French Department from 1924 to1929 and wrote a satirical novel about his McGill experiences, Smith Conundrum, had his autobiographical protagonist complain that McGill's janitors were more important than faculty deans: $1^{\text {st }}$ edition, Querqueville, France, 1942, 2nd edition, Ex Nihilo, Paris, 2010, with preface by Marc Angenot, postface (afterword) by Robert Michel, 158-159 of latter edition.

${ }^{28}$ Trott slippingly recalled it as "King Cole." His chronology vague, he implies the crowning was close to Christmas, rather than the actual date of 1 April 1919 and that this was King Cook the Ninth when he was only the Third: Campus Shadows, 76-77.

${ }^{29}$ McGill Daily, 25 March 1919, 1.

${ }^{30}$ McGill Daily, 1 April 1919, 1.

${ }^{31}$ McGill Daily, 2 April 1919, 1, 2. Montreal Mayor M. Martin was of course the only one on the list who could have attended — if he did...

${ }^{32}$ Letter, Robert Langford, Child's Restaurant, to Paul Mallinson, President, Student Council, 13 Nov. 1928, McGill University Archives, Principals' Fonds, RG2, C49, file 583 "Student Activities and Discipline, 1920-1937."

${ }^{33}$ This last moment of health, looking at shadows fall across the campus, is the image in the title Campus Shadows and on the book cover (improved retrospectively by the Roddick Gates, unbuilt in 1919; after their construction in 1925, this Greek-columned crescent at the campus entrance came to symbolize McGill): see Fontanus IX, 82.

${ }^{34}$ Recovery became the rule as clinical treatment and neurological science improved. A history and description of the disease is given by Patricia L. Tikkanen, "LandryGuillan-Barré-Strohl Syndrome," Journal of Neurosurgical Nursing, April 1982, Vol. 14, No. 2, 74-81. Colin K. Russel was Lecturer in Neurology at this time; later Professor, he taught at McGill from 1906 to 1945. A.E. Orr was Lecturer in Anatomy at the time and taught at McGill from 1897 to 1920 .

35 On Russel, see W. Penfield, W.W. Francis, and F.L. McNaughton, "Tributes to Colin Kerr Russel 1877. 1956 at the Montreal Neurological Institute, October 10, 1956," Reprint, The Canadian Medical Association Journal, Oct. 1, 1957, 77,715-723. Noting Trott's grateful praise of Russel in Campus Shadows, McNaughton states that artificial respiration turned out to be unnecessary in Trott's case. Russel served in both World Wars, in the second as a Colonel; Trott occasionally confuses his first name "Colin" with "Colonel" and spelled Russel as "Russell" in his text. Russel's work is summarized in: Joseph Hanaway, Richard Cruess, and James Darragh, McGill Medicine, Volume 2, 1885-1936, McGill Queen's Press, Montreal \& Kingston, 2006, 164. Trott's case is mentioned in Preston Robb, The Development of Neurology at McGill (Montreal, the author, 1989), 24.

${ }^{36}$ Jessie Boyd Scriver, "Slowly the Doors Opened", Collard, The McGill You Knew, 132-133; on early women medical students, see Margaret Gillett, We Walked Very Warily, Eden Press, Montreal, 1981, 279-303, especially 298: Scriver wrote that the McGill women were treated comparatively well because "We walked very warily."

${ }^{37}$ McGill Daily, 14 Dec. 1918, 3, in the column "Quips". Apparently a self-appointed group of men visited Jessie Boyd at home in fall 1918 to ask her and the other women to resign: Hanaway, Cruess, and Darragh, McGill Medicine, Volume 2, 1885-1936, 109. There is no mention by Trott of the women medical students at McGill.

${ }^{38}$ Hanaway, Cruess, and Darragh, McGill Medicine, Volume 2, 1885-1936, 109.

${ }^{39}$ Letters, F.D. Adams to H.S. Birkett, 4 June 1920, Birkett to Adams, 25 June 1920, McGill University Archives, Principals' Fonds, RG 2, C67, file 1246: "Medicine General", 1918-1926. It was contemplated to extend the medical year, which would have cut down on summer work.

${ }^{40}$ In 1913, University of Alberta set up a Faculty of Medicine to train the first three years of the standard Canadian five year program, arranging that the final two years be taken at University of Toronto or McGill. By 1925, partly through Rockefeller Foundation support, Alberta was able to train for all five years, although McGill continued to accept transfers on individual merits. See letters between Augustus Downing, University of the State of New York, Albany, and Principal Currie and the Secretary, Faculty of Medicine, Sept. 1925, McGill University Archives, Principals' Fonds, RG2, C67, file 1246: "Medicine - General - 1918-1926". There is a spoof history of the medical class of 1924 in Old McGill (1924), 58, 269. It names no individuals but probably refers to Trott's Alberta friends: "A class hyperplasia occurred due to the influx of a group of Western Brethren..."

${ }^{41}$ Trott called him “Joe" earlier, Campus Shadows, 75 